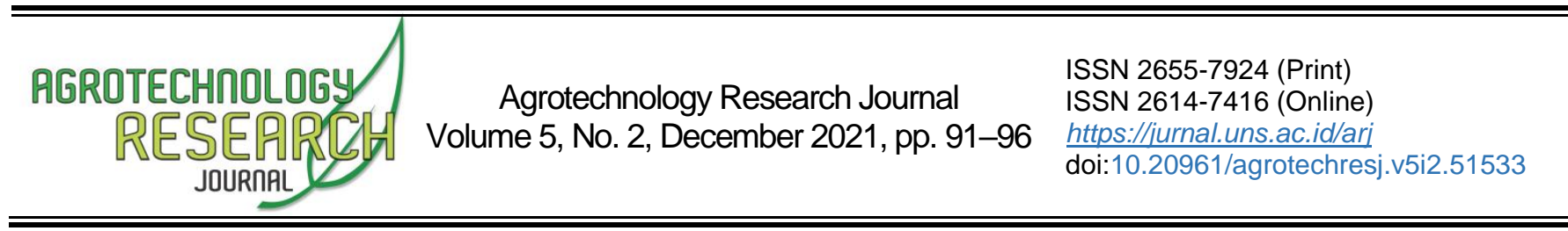

\title{
Respons Hasil Padi dan Hara Tanah Sawah terhadap Bakteri Pelarut Fosfat dan Pemfiksasi Nitrogen
}

\section{Response of Rice Yield and Soil Nutrients to Phosphate Solubilizing Bacteria and Nitrogen Fixer}

\author{
Muhimmatul Husna $^{1 *}$, Sugiyanta ${ }^{2}$, Etty Pratiwi ${ }^{3}$ \\ ${ }^{1}$ Department of Agricultural Cultivation, Faculty of Agriculture, Universitas Bengkulu, Bengkulu, Sumatera, 38371, Indonesia \\ ${ }^{2}$ Department of Agronomy and Horticulture, Faculty of Agriculture, Institut Pertanian Bogor, Bogor, Jawa Barat, 16680, Indonesia \\ ${ }^{3}$ Indonesian Soil Research Institute, Bogor, Jawa Barat, 16114, Indonesia
}

Received 27 May 2021; Accepted 20 October 2021; Published 31 December 2021

\begin{abstract}
The condition of unfertile paddy field due to excessive inorganic fertilizer application causing soil degradation. Fertilizing techniques using phosphate solubilizing and nitrogen fixer bacteria are breakthroughs that should be developed in paddy cultivation to increase fertility soil and harvest of rice. This research aims to study on phosphate solubilizing and nitrogen fixer bacteria ability to increase the harvest of rice by increasing chemical and biological fertility of soil. The research was conducted in the greenhouse of Sawah Baru experimental garden, IPB University. The design used was a completely randomized design with one factor that was dosage of inorganic fertilizers (NPK) with seven levels that were control, NPK $100 \%$, NPK $0 \%$ + bacteria, NPK $25 \%$ + bacteria, NPK $50 \%$ + bacteria, NPK $75 \%$ + bacteria and NPK 100\% + bacteria. Each stage was repeated four times, so there were 28 units. The results of phosphate solubilizing and nitrogen fixer bacteria could produce more rice grain 0.32 ton.ha ${ }^{-1}$ than NPK $100 \%$ (recommended dose). Biological soil fertility improved with the increased population of bacteria, but there was no improved soil chemical fertility of soil.
\end{abstract}

Keywords: biological fertility; chemical fertility, grain; NPK; soil nutrient

Cite this as (CSE Style): Husna M, Sugiyanta, Pratiwi E. 2021. Respons hasil padi dan hara tanah sawah terhadap bakteri pelarut fosfat dan pemfiksasi nitrogen. Agrotechnology Res J. 5(2):91-96. https://dx.doi.org/10.20961/agrotechresj.v5i2.51533.

\section{PENDAHULUAN}

Tanah sawah telah banyak mengalami degradasi yang mengakibatkan menurunnya produksi padi di Indonesia. Hanya $4 \%$ lahan sawah tidak terdegradasi pada 8 provinsi pusat produksi padi, $8 \%$ terdegradasi ringan dan lainnya terdegradasi sedang dan berat (Mulyani et al. 2012). Lahan sawah yang mengalami degradasi ditandai dengan penurunan produktivitas tanah, kandungan $\mathrm{C}$ organik dan hara $\mathrm{N}$ dan $\mathrm{P}$. Tanah sawah yang terdegradasi memiliki hara fosfat sedikit tersedia karena cenderung membentuk ikatan kompleks dengan Al dan Fe (Soepandi 2014).

Selain itu, degradasi terhadap biologi tanah ditandai dengan penurunan kualitas dan kuantitas bahan organik tanah dan aktivitas mikroba tanah. Penggunaan pupuk $\mathrm{N}$ kimia secara berturut-turut dapat menekan populasi

${ }^{*}$ Corresponding Author:

E-Mail':mhusna@unib.ac.id dan keberagaman spesies bakteri dalam sawah yang mempengaruhi produksi padi (Kumar et al. 2018). Akibatnya kondisi biologi tanah menjadi menurun.

Rehabilitasi tanah sawah terdegradasi dapat dilakukan dengan pemberian mikroba yang dapat meningkatkan ketersediaan hara makro. Mikroba memiliki kemampuan melarutkan fosfat dalam tanah dan memfiksasi $\mathrm{N}_{2}$. Mekanisme yang terjadi pada mikroba pelarut fosfat meliputi sekresi asam organik dan enzim ekstraseluler fosfatase (Vandana et al. 2017). Fiksasi $\mathrm{N}_{2}$ adalah salah satu komponen penting dalam input hara di tanah sawah (Dobermann dan Fairhurst 2000), sehingga bakteri pemfiksasi nitrogen sangat penting diberikan pada tanah sawah untuk meningkatkan ketersediaan unsur hara $\mathrm{N}$.

Salah satu spesies mikroba yang dapat melarutkan fosfat dan pengikat nitrogen atau pemfiksasi nitrogen adalah Bacillus sp. Bacillus sp. merupakan bakteri free living dan inokulan tanah yang memfiksasi nitrogen dalam jangka panjang (Satapute et al. 2012). Berdasarkan hasil uji kemampuan bakteri Bacillus sp. yang terdapat dalam pupuk hayati oleh Husna et al. 
(2019), Bacillus sp. dapat memfiksasi $\mathrm{N}_{2}$ dengan nilai aktivitas nitrogenase $0.0568 \mathrm{~m} \mathrm{~m} \mathrm{~m}^{-1} \mathrm{jam}^{-1}$, melarutkan hara fosfat dengan indeks pelarut fosfat 2.6 serta memproduksi empat jenis asam organik.

Aplikasi bakteri pelarut fosfat dan pemfiksasi $\mathrm{N}_{2}$ telah banyak dimanfaatkan pada usaha tani untuk meningkatkan hasil. Namun demikian, potensi bakteri pelarut fosfat dan pemfiksasi $\mathrm{N}_{2}$ dalam meningkatkan kesuburan tanah khususnya tanah sawah yang terdegradasi tidak banyak diketahui. Oleh sebab itu, perlu dilakukan pengujian pengaruh aplikasi bakteri pelarut fosfat dan pemfiksasi nitrogen pada sawah yang terdegradasi. Tujuan penelitian ini adalah mengetahui kemampuan bakteri pelarut fosfat dan pemfiksasi nitrogen untuk meningkatkan kesuburan tanah berupa sifat kimia dan biologi tanah sawah serta meningkatkan hasil padi.

\section{BAHAN DAN METODE}

Penelitian dilakukan pada bulan November 2018 sampai Maret 2019 di rumah plastik Kebun Percobaan Sawah Baru IPB, Darmaga, Bogor, Jawa Barat $\left(6,56^{\circ} \mathrm{LS}, 106,73^{\circ} \mathrm{BT}\right.$. Bahan yang digunakan adalah benih padi varietas IPB3S, konsorsium bakteri, pupuk kandang, pupuk urea, SP36 dan $\mathrm{KCl}$. Alat yang digunakan adalah ember ukuran $30 \mathrm{~cm} \times 30 \mathrm{~cm}$, bak plastik, hand sprayer ukuran $1 \mathrm{~L}$ dan Portable Photosynthesis System Model Li 6400XT (Li-cor).

Rancangan percobaan untuk pengujian pupuk hayati dilakukan berdasarkan pada Peraturan Menteri Pertanian No.70/Permentan/SR.140/10/2011 Tentang Pupuk Organik, Pupuk Hayati dan Pembenah Tanah. Rancangan yang digunakan adalah Rancangan Acak Lengkap (RAL) dengan 1 faktor yaitu dosis pupuk anorganik (NPK) dengan tujuh taraf, yaitu kontrol, NPK $100 \%$, NPK 0\%+bakteri, NPK 25\%+bakteri, NPK 50\%+bakteri, NPK 75\%+bakteri dan NPK 100\%+bakteri. Masing-masing taraf diulang empat kali ulangan sehingga terdapat 28 satuan percobaan.

Analisis tanah awal menggunakan PUTK (Perangkat Uji Tanah Kering) untuk menentukan dosis NPK rekomendasi. Hasil analisis uji PUTK menunjukkan bahwa C-organik rendah, $\mathrm{pH}$ agak masam, kadar $\mathrm{P}$ dan $\mathrm{K}$ sedang sehingga dosis rekomendasi $100 \%$ untuk kondisi tanah adalah urea $200 \mathrm{~kg} \cdot \mathrm{ha}^{-1}$, SP36 $150 \mathrm{~kg} \cdot \mathrm{ha}^{-1}$

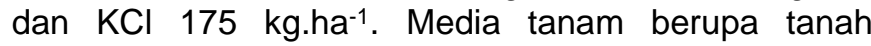
ditambah dengan pupuk kandang dan kompos jerami masing-masing sebanyak $15 \mathrm{~g}$ per pot. Bakteri pelarut fosfat dan pemfiksasi nitrogen diaplikasikan ke benih padi berupa pupuk hayati cair. Uji kemampuan bakteri untuk melarutkan fosfat dan memfiksasi nitrogen dalam pupuk hayati cair telah diteliti terlebih dahulu dan disajikan pada Husna et al. (2019). Pupuk hayati yang digunakan terdiri dari bakteri Bacillus sp. Benih padi dengan perlakuan pupuk hayati direndam selama 24 jam kemudian ditiriskan dan diinokulasi dengan konsorsium bakteri selama 24 jam. Benih padi disebar pada bak plastik. Bibit dipindahkan ke ember setelah berumur 2 minggu. Setiap ember ditanam 2 bibit padi. Aplikasi bakteri dilakukan dengan cara disemprot pada 2,4,6 dan 8 minggu setelah pindah tanam (MSPT) ke arah bagian bawah daun dan permukaan tanah dengan dosis 2 L.ha1. Pupuk urea sebanyak $60 \%$ diaplikasikan pada 1 minggu setelah pindah tanam (MSPT) sama dengan SP36 dan $\mathrm{KCl}$ dan $40 \%$ pupuk urea sisanya diaplikasikan pada 4 MSPT.

Parameter yang diamati berupa laju fotosintesis, jumlah malai per tanaman, jumlah biji per malai, bobot gabah (ton.ha- ${ }^{-1}$ ) dan persentase gabah isi. Data yang diperoleh dianalisis Anova untuk mengetahui pengaruh perlakuan dan diuji lanjut dengan Duncan's Multiple Range Test (DMRT) taraf 5\%. Adapun sifat kimia tanah dan biologi tanah yang diuji adalah $\mathrm{P}$ tersedia, $\mathrm{N}$ total, $\mathrm{P}$ total, dan $\mathrm{K}$ total dan populasi bakteri Bacillus sp.

\section{HASIL DAN PEMBAHASAN \\ Laju fotosintesis padi}

Nilai laju fotosintesis padi yang diukur pada saat fase vegetatif dipengaruhi oleh perlakuan aplikasi bakteri dengan pupuk NPK. Berdasarkan hasil uji anova taraf $5 \%$, laju fotosintesis pada perlakuan pupuk NPK dan bakteri pelarut fosfat dan pemfiksasi nitrogen berbeda nyata. Hasil uji lanjut DMRT taraf $5 \%$ yang disajikan pada Tabel 1 diperoleh laju fotosintesis perlakuan pupuk NPK $100 \%$ paling tinggi diantara perlakuan lainnya meskipun tidak berbeda nyata dengan perlakuan NPK $0 \%$ dan perlakuan yang dikombinasikan dengan bakteri, NPK $75 \%+$ bakteri dan NPK 100\%+bakteri. Hal ini karena pada fase vegetatif padi menyerap banyak nitrogen yang merupakan unsur penting dalam pembentukan klorofil sehingga laju fotosintesis pada perlakuan tidak berbeda nyata.

Laju fotosintesis dipengaruhi oleh kandungan klorofil pada daun, unsur nitrogen dalam klorofil dapat memicu laju fotosintesis (Hidayati et al. 2016). Hal ini terlihat pada Gambar 1 yang menunjukkan adanya korelasi antara laju fotosintesis dengan kandungan $\mathrm{N}$ tanaman. Tingginya laju fotosintesis akan meningkatkan kandungan hara $\mathrm{N}$ jerami.

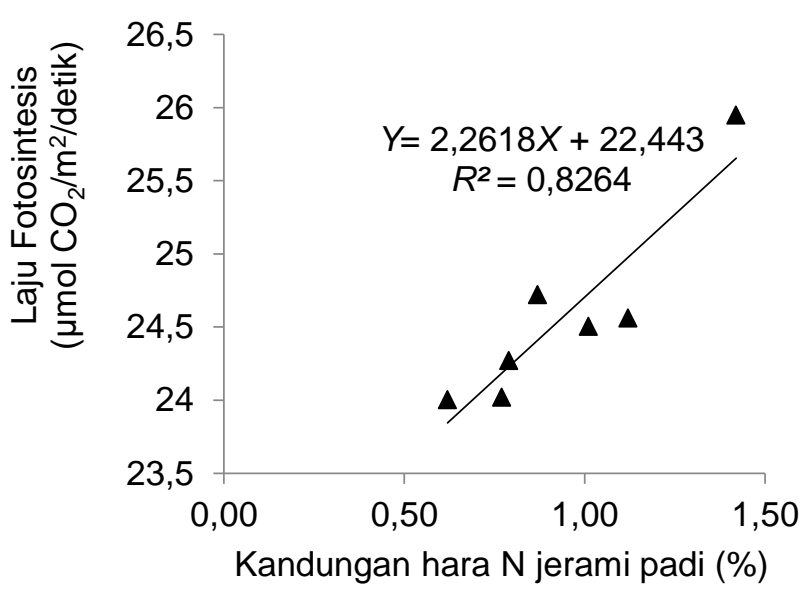

Gambar 1. Korelasi laju fotosintesis dengan kandungan hara $\mathrm{N}$ jerami padi 
Tabel 1. Laju fotosintesis dan komponen hasil padi pada perlakuan pupuk NPK, bakteri pelarut fosfat dan pemfiksasi nitrogen

\begin{tabular}{lccccc}
\hline Perlakuan & $\begin{array}{c}\text { Laju fotosintesis } \\
\left(\mu \mathrm{mol} \mathrm{CO} / \mathrm{m}^{2} / \text { detik }\right)\end{array}$ & $\begin{array}{c}\text { Jumlah malai } \\
\text { per rumpun }\end{array}$ & $\begin{array}{c}\text { Jumlah biji per } \\
\text { malai }\end{array}$ & $\begin{array}{c}\text { Bobot gabah } \\
\left(\text { ton.ha }{ }^{-1}\right)\end{array}$ & $\begin{array}{c}\text { Gabah isi } \\
(\%)\end{array}$ \\
\hline Kontrol & $24,50 \mathrm{ab}$ & $6,98 \mathrm{~b}$ & 129,03 & $2,00 \mathrm{~b}$ & $45,16 \mathrm{a}$ \\
NPK 100\% & $25,94 \mathrm{a}$ & $12,99 \mathrm{a}$ & 143,13 & $4,00 \mathrm{a}$ & $54,28 \mathrm{ab}$ \\
NPK 0\% +bakteri & $24,02 \mathrm{~b}$ & $7,00 \mathrm{~b}$ & 126,03 & $1,79 \mathrm{~b}$ & $43,78 \mathrm{a}$ \\
NPK 25\% +bakteri & $24,27 \mathrm{~b}$ & $8,15 \mathrm{~b}$ & 126,43 & $2,53 \mathrm{~b}$ & $52,70 \mathrm{ab}$ \\
NPK 50\% +bakteri & $24,00 \mathrm{~b}$ & $11,16 \mathrm{a}$ & 121,55 & $3,69 \mathrm{a}$ & $59,80 \mathrm{~b}$ \\
NPK 75\% + bakteri & $24,56 \mathrm{ab}$ & $12,08 \mathrm{a}$ & 139,38 & $4,32 \mathrm{a}$ & $60,63 \mathrm{~b}$ \\
NPK 100\% +bakteri & $24,71 \mathrm{ab}$ & $13,16 \mathrm{a}$ & 136,35 & $4,19 \mathrm{a}$ & $56,66 \mathrm{ab}$ \\
\hline
\end{tabular}

Keterangan: Huruf yang sama pada kolom tidak berbeda nyata berdasarkan pada uji DMRT taraf $5 \%$.

\section{Komponen hasil padi}

Jumlah malai per rumpun dan bobot gabah padi dipengaruhi oleh aplikasi bakteri pelarut fosfat dan pemfiksasi nitrogen (Tabel 1). Jumlah malai per rumpun paling tinggi pada perlakuan NPK $100 \%$ + bakteri sebanyak 13 malai, tidak berbeda nyata dengan perlakuan NPK $100 \%$. Bobot gabah paling tinggi dihasilkan pada perlakuan NPK $75 \%$ + bakteri mencapai 4,32 ton/ha. Berdasarkan pada uji DMRT 5\%, bobot gabah pada perlakuan NPK $100 \%$ tidak berbeda nyata dengan perlakuan NPK $50 \%$ dan $75 \%$ yang diaplikasikan dengan bakteri. Aplikasi mikroba pelarut fosfat dapat meningkatkan hasil gabah, selain itu juga dapat meningkatkan serapan hara $\mathrm{P}$ pada jerami dan gabah (Puspitawati et al. 2013).

Nilai yang diperoleh menunjukkan bahwa pengurangan pupuk NPK hingga $50 \%$ yang ditambah dengan aplikasi bakteri pelarut fosfat dan bakteri pemfiksasi nitrogen dapat memberikan hasil yang tidak berbeda nyata dengan pupuk NPK rekomendasi. Suplai $50 \%$ hara $\mathrm{N}, \mathrm{P}$ dan $\mathrm{K}$ yang dibutuhkan oleh tanaman padi dapat dipenuhi oleh bakteri yang diaplikasikan. Namun, pada perlakuan NPK $0 \%+$ bakteri justru menghasilkan bobot gabah yang lebih rendah dari kontrol. Hal ini terjadi karena bakteri memerlukan energi untuk bermetabolisme berupa nitrogen, nitrogen yang tersedia di tanah sawah sebagian digunakan oleh bakteri dan sebagian diserap oleh padi. Perlakuan ini tidak diberi pupuk NPK sehingga hara N sedikit tersedia bagi tanaman yang menyebabkan hasil padi sedikit.

Tingginya bobot gabah padi pada perlakuan NPK $75 \%$ + bakteri didukung dengan persentase gabah isi yang tinggi. Persentase gabah isi perlakuan NPK $75 \%+$ bakteri paling tinggi yaitu $60,63 \%$, tidak berbeda nyata dengan perlakuan NPK $50 \%+$ bakteri sebanyak $59,80 \%$. Sedangkan pada perlakuan dosis NPK $100 \%$ persentase gabah isi hanya $54,28 \%$. Hal ini sejalan dengan penelitian Purwani et al. (2018) pada perlakuan kombinasi bakteri dengan NPK $50 \%-75 \%$ dari dosis rekomendasi menghasilkan jumlah gabah isi lebih banyak daripada perlakuan NPK dosis rekomendasi. Nilai komponen hasil padi terdapat pada Tabel 1.

Hasil gabah yang diperoleh pada perlakuan NPK $75 \%+$ bakteri tidak berbeda nyata dengan perlakuan
NPK $100 \%$. Artinya, penambahan bakteri pelarut fosfat dapat menyediakan kebutuhan hara $P$ untuk pertumbuhan dan perkembangan tanaman padi yang menggantikan penggunaan pupuk NPK sebanyak $25 \%$. Aplikasi pupuk hayati pada tanaman dapat menurunkan kebutuhan $\mathrm{N}$ bagi tanaman sebanyak 25\% (Panhwar et al. 2019). Walaupun hasil uji $P$ total dan $P$ tersedia tidak lebih besar dari perlakuan tanpa aplikasi bakteri. Bakteri pelarut fosfat berperan dalam ketersediaan $\mathrm{P}$ tanah (Dermiyati et al. 2009).

\section{Pengaruh aplikasi bakteri pelarut fosfat dan fiksasi nitrogen terhadap sifat kimia tanah sawah}

Berdasarkan pada hasil analisis yang disajikan pada Tabel 2, hara tanah awal, $\mathrm{pH}$ tanah 5,4 dan setelah aplikasi pemberian perlakuan bakteri $\mathrm{pH}$ tanah naik menjadi 5,5 - 5,7. Meskipun kenaikan $\mathrm{pH}$ tanah tidak tinggi, aplikasi bakteri pelarut fosfat dan pemfiksasi nitrogen pada budidaya padi sawah dapat menaikkan $\mathrm{pH}$ tanah. Hasil analisis $\mathrm{C}$ organik tanah awal sebesar $1,83 \%$. Setelah pemupukan NPK dan aplikasi bakteri, C organik yang terkandung pada tanah penelitian berbedabeda. Pada perlakuan tanpa aplikasi bakteri dan tanpa pupuk NPK, C organik tanah 1,94\% dan dengan pupuk NPK $1,93 \%$, sedangkan C organik tanah pada perlakuan aplikasi bakteri 1,80\% - 2,01\%. Kondisi ini terjadi karena bakteri memanfaatkan $\mathrm{C}$ organik sebagai sumber energi dalam perkembangannya sehingga $\mathrm{C}$ organik pada perlakuan yang diaplikasi bakteri lebih rendah daripada C organik pada perlakuan tanpa bakteri. Berdasarkan hasil uji Cecilia et al. (2019) terdapat efek gabungan represi katabolit dan memori mikroba (Memory Associated Catabolite Repression for Carbon (MACR-C) yang mempengaruhi bakteri untuk mengkonsumsi substrat sumber karbon yang lebih tersedia seperti karbon dari bahan organik.

Salah satu faktor rendahnya $C$ organik pada tanah yang diaplikasi bakteri adalah kurangnya bahan organik yang diberikan pada penelitian ini yaitu kompos jerami padi dan pupuk kandang. Kompos jerami mengandung $\mathrm{C}$ organik dan $\mathrm{N}$ total tinggi sehingga baik digunakan sebagai bahan organik pada tanah sawah (Kasno et al. 2017). 
Tabel 2. Pengaruh perlakuan NPK dan bakteri (pelarut fosfat dan pemfiksasi nitrogen) terhadap ketersediaan hara $\mathrm{N}, \mathrm{P}$ dan $\mathrm{K}$ tanah

\begin{tabular}{|c|c|c|c|c|c|c|c|}
\hline \multirow[b]{2}{*}{ Perlakuan } & \multirow[b]{2}{*}{$\mathrm{pH}$} & \multirow{2}{*}{$\begin{array}{c}\text { C organik } \\
(\%)\end{array}$} & \multirow{2}{*}{$\frac{\text { P Tersedia }}{\text { ppm }}$} & \multirow[t]{2}{*}{ N Total } & \multirow{2}{*}{$\begin{array}{l}\text { P Total } \\
\%\end{array}$} & \multirow[t]{2}{*}{ K Total } & \multirow{2}{*}{$\begin{array}{c}\text { Populasi } \\
\text { Bakteri } \\
\text { (cfu.ml-1 }^{-1} \text { ) }\end{array}$} \\
\hline & & & & & & & \\
\hline Sebelum Tanam & 5,4 & 1,83 & 80 & 0.14 & 0.12 & 0.04 & $1,6 \times 10^{7}$ \\
\hline Tanpa pelakuan & 5,7 & 1,94 & 80 & 0.14 & 0.11 & 0.04 & $2,0 \times 10^{7}$ \\
\hline NPK $100 \%$ & 5,7 & 1,93 & 74 & 0.13 & 0.11 & 0.03 & $1,9 \times 10^{7}$ \\
\hline NPK 0\% +bakteri & 5,7 & 1,82 & 86 & 0.14 & 0.20 & 0.03 & $3,68 \times 10^{6}$ \\
\hline NPK 25\% +bakteri & 5,6 & 2,01 & 77 & 0.13 & 0.10 & 0.03 & $3,492 \times 10^{8}$ \\
\hline NPK 50\% +bakteri & 5,5 & 1,80 & 77 & 0.15 & 0.10 & 0.03 & $6,852 \times 10^{8}$ \\
\hline NPK 75\% + bakteri & 5,5 & 1,85 & 77 & 0.14 & 0.11 & 0.03 & $1,46 \times 10^{9}$ \\
\hline NPK 100\% +bakteri & 5,5 & 1,84 & 64 & 0.15 & 0.11 & 0.03 & $4,688 \times 10^{8}$ \\
\hline
\end{tabular}

$\mathrm{N}$-total dalam tanah mengalami peningkatan pada perlakuan NPK $50 \%+$ bakteri dan NPK $100 \%+$ bakteri sebanyak $0,01 \%$. Namun, $\mathrm{N}$ total pada perlakuan penambahan bakteri tidak berubah dari kandungan $\mathrm{N}$ sebelum tanam. Hal yang sama juga terjadi pada $P$ dan $\mathrm{K}$ total dalam tanah. Hara $\mathrm{P}$ dan $\mathrm{K}$ total pada tanah penelitian setelah diaplikasikan bakteri tidak mengalami kenaikan. Hara nitrogen dalam tanah telah diserap oleh tanaman sehingga hasil uji hara $\mathrm{N}, \mathrm{P}$ dan $\mathrm{K}$ total setelah panen tidak mengalami peningkatan.

Berdasarkan hasil penelitian sebelumnya oleh Husna et al. (2019), bakteri Bacillus sp. yang diaplikasikan pada penelitian ini dapat memfiksasi nitrogen melalui uji nitrogenase, Bacillus sp. dapat memfiksasi nitrogen dengan rata-rata $0.0568 \mu \mathrm{m} \cdot \mathrm{ml}^{-1}$.jam ${ }^{-1}$. Hasil pengujian fiksasi nitrogen di laboratorium tinggi, namun mekanisme fiksasi nitrogen oleh bakteri ketika di tanah sawah berbeda karena dipengaruhi oleh faktor lingkungan. Hara $\mathrm{N}$ total tidak mengalami peningkatan pada tanah sawah karena sifat hara $\mathrm{N}$ yang mobile dan aktivitas bakteri dipengaruhi oleh sumber energi berupa karbon untuk mereduksi asetilen menjadi etilen (Gyaneshwar et al. 2001). Tidak adanya peningkatan hara $\mathrm{N}, \mathrm{P}$ dan $\mathrm{K}$ total juga terjadi pada hasil penelitian Irawati dan Kusnanto (2017), pemberian bakteri pelarut fosfat berupa pupuk hayati pada tanah sawah tidak menunjukkan perubahan yang signifikan.

Aplikasi bakteri tidak memberikan perubahan signifikan pada N, P dan K total, tetapi aplikasi bakteri dapat meningkatkan hara $P$ tersedia. Tanah yang diaplikasikan bakteri memiliki $P$ tersedia lebih tinggi dari perlakuan pemupukan NPK rekomendasi. Bakteri melarutkan fosfat melalui dua mekanisme yaitu mensekresi asam organik dan mengkelat $\mathrm{Al}^{2+}$ dan $\mathrm{Fe}^{2+}$ dan melepaskan $\mathrm{HPO}_{4}^{-}$(Jha dan Saraf 2015). Berdasarkan hasil uji sekresi asam organik oleh bakteri yang digunakan pada penelitian ini, bakteri Bacillus sp. mensekresi empat jenis asam organik yaitu asam asetat, asam oksalat, asam laktat dan asam malat (Husna et al. 2019). Asam oksalat lebih efektif melarutkan hara $P$ daripada asam malat, selain itu asam organik juga mempengaruhi penyerapan hara $\mathrm{P}$ bagi tanaman (Panhwar et al. 2013). Sifat bakteri pelarut fosfat berkorelasi dengan asam organik melalui direct oxidation pathway yang terjadi di luar permukaan membran sitoplasma (Zaidi et al. 2009).

\section{Populasi bakteri pada tanah sawah}

Populasi bakteri di tanah berpengaruh terhadap hasil padi (Gambar 2). Terdapat korelasi positif antara populasi bakteri di tanah dengan hasil padi. Populasi bakteri pelarut fosfat dan pemfiksasi nitrogen yang semakin banyak di tanah sawah dapat meningkatkan hasil padi. Populasi bakteri Bacillus sp. paling banyak pada perlakuan NPK $75 \%+$ bakteri $\left(1,46 \times 10^{9} \mathrm{cfu}^{\mathrm{ml} l^{-1}}\right)$ dengan bobot gabah paling tinggi $\left(4,32\right.$ ton.ha- $\left.{ }^{-1}\right)$. Proses biologi tanah akan berpengaruh pada pertanian berkelanjutan yang mengutamakan sumber daya alam (Vyas et al. 2017). Artinya peningkatan populasi bakteri pada tanah sawah dapat meningkatkan kesuburan tanah sawah dalam jangka panjang.

Tabel 2 menunjukkan populasi bakteri terbanyak pada perlakuan NPK $75 \%+$ bakteri kemudian NPK 50\%+bakteri, NPK 100\%+bakteri, NPK 25\%+bakteri, kontrol, NPK 100\%, NPK 0\%+bakteri. Populasi bakteri perlakuan NPK $0 \%+$ bakteri paling sedikit meskipun bakteri telah diaplikasikan. Pada kondisi tanah dengan input $\mathrm{N}$ rendah terjadi aktifitas mikroba pemfiksasi nitrogen 2,5 kali lebih tinggi daripada tanah sawah input $\mathrm{N}$ tinggi (Pandey et al. 2021). Hal ini berbeda dengan kondisi NPK $0 \%$ + bakteri yang tidak terdapat input $\mathrm{N}$ sehingga bakteri tidak dapat berkembang dengan baik karena kondisi tanah yang kurang karbon dan nitrogen sebagai sumber energi bakteri.

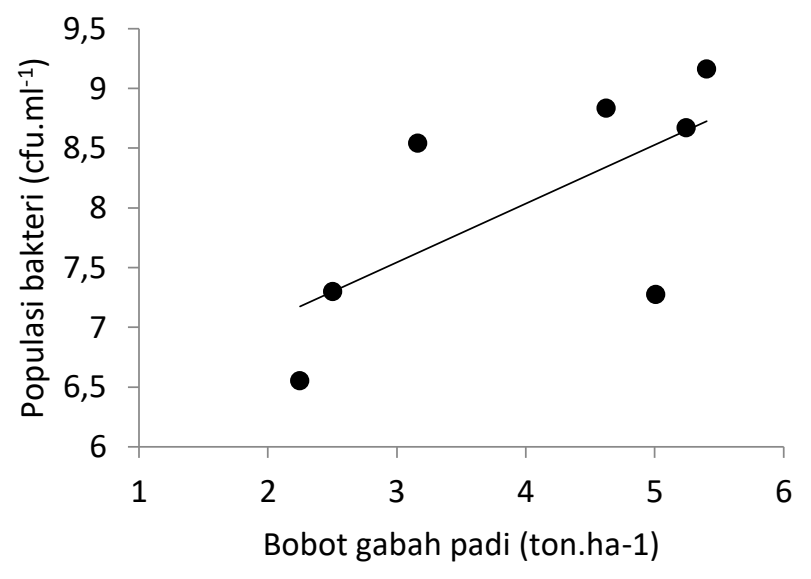

Gambar 2. Korelasi Populasi bakteri dengan bobot gabah padi 


\section{KESIMPULAN}

Hasil penelitian diperoleh aplikasi bakteri pelarut fosfat dan pemfiksasi nitrogen dapat meningkatkan hasil padi dengan gabah padi lebih banyak 0,32 ton. ha ${ }^{-1}$ atau $7,8 \%$ dari NPK $100 \%$ (dosis rekomendasi). Terdapat perbaikan sifat biologi tanah sawah pada perlakuanperlakuan NPK $75 \%+$ bakteri dengan populasi bakteri mencapai 25,9\% lebih banyak daripada NPK 100\%, tapi tidak terjadi perubahan pada sifat kimia tanah sawah.

\section{UCAPAN TERIMA KASIH}

Terima kasih penulis ucapkan kepada Lembaga Pengelola Dana Pendidikan (LPDP) yang telah mendanai penelitian ini pada skim pengajuan Dana Pendidikan Dana Penelitian dan Ujian Tesis/Disertasi dengan pengajuan Nomor FR11102018159139.

\section{DAFTAR PUSTAKA}

Cecilia D, Riley WJ, Maggi F. 2019. Biochemical modeling of microbial memory effects and catabolite repression on soil organic carbon compounds. Soil Biol Biochem. 128:1-12. https://doi.org/10.1016/j.soilbio.2018.10.003.

Dermiyati, Antari J, Yusnaini S, Nugroho SG. 2009. Perubahan populasi mikroorganisme pelarut fosfat pada lahan sawah dengan sistem pertanian intensif menjadi sistem pertanian organik berkelanjutan. J Tanah Trop.14(2):143-148.

Dobermann A, Fairhurst TH. 2000. Rice: nutrient disorders \& nutrient management. Handbook series. Oxford Graphic Printers Pte Ltd.

Gyaneshwar P, James EK, Mathan N, Reddy PM, Hurek BR, Ladha JK. 2001. Endophytic colonization of rice by a diazotrophic strain of Serratia marcescens. J Bacteriol. 183(8):2634-2645. https://doi.org/10.1128/JB.183.8.2634-2645.2001.

Hidayati N, Triadiati, Anas I. 2016. Photosynthesis and transpiration rates of rice cultivated under the system of rice intensification and the effects on growth and yield. Hayati J of Biosci. 23(2):67-72. https://doi.org/10.1016/j.hjb.2016.06.002.

Husna M, Sugiyanta, Pratiwi E. 2019. Kemampuan konsorsium Bacillus pada pupuk hayati dalam memfiksasi $\mathrm{N}_{2}$, melarutkan fosfat dan mensintesis fitohormon Indole-3-Acetic-Acid. J Tanah Iklim. 43(2):113-121.

http://dx.doi.org/10.21082/jti.v43n2.2019.117-125.

Irawati A, Kusnanto T. 2017. Pengaruh aplikasi pupuk hayati terhadap sifat kimia tanah pada lahan sawah. In: Dermiyati, Niswati A, Yusnaini S, Yuliana N, Hasanuddin U, Erwanto, Hidayat KF, Aji S, Kusarpoko B, Rivaie AA, et al, editor. Agroinovasi spesifik lokasi untuk memantapkan ketahanan pangan pada era masyarakat ekonomi ASEAN. Prosiding Seminar Nasional "Agroinovasi Spesifik Lokasi untuk Ketahanan Pangan pada Era Masyarakat Ekonomi ASEAN"; 19-20 Oktober 2016; Bandar Lampung, ID. Bogor (ID): Balai Besar Pengkajian dan Pengembangan Teknologi Pertanian. pp. 272-278.
Jha CK, Saraf M. 2015. Plant growth promoting rhizobacteria (PGPR): a review. E3 J Agric Res Dev. 5(2):108-119.

Kasno A, Irawan, Husnain, Rochayati S. 2017. Integrated nutrient management acid paddy soil in Karang Tanjung village, Padang Ratu, Central Lampung. J Trop Soils. 22(2):97-106.

Kumar U, Nayak AK, Shahid M, Gupta VVSR, Panneerselvam P, Mohanty S, Kaviraj M, Kumar A, Chatterjee D, Lal B, et al. 2018. Continuous application of inorganic and organic fertilizers over 47 years in paddy soil alters the bacterial community structure and its influence on rice production. Agric Ecosyst Environ. 262:65-75. https://doi.org/10.1016/j.agee.2018.04.016.

Mulyani A, Setyorini D, Rochayati S, Las I. 2012. Karakteristik dan sebaran lahan sawah terdegradasi di 8 provinsi sentra produksi padi. In: Wigena $P$, Nurida NL, Setyorini D, Husnain, Husen E, Suryani E, editor. Teknologi pemupukan dan pemulihan lahan terdegradasi. Prosiding Seminar Nasional "Teknologi Pemupukan dan Pemulihan Lahan Terdegradasi". Bogor (ID): Balai Besar Penelitian dan Pengembangan Sumberdaya Lahan Pertanian. pp. 99-110.

Pandey A, Suter H, He JZ, Hu HW, Chen D. 2021. Dissimilatory nitrate ammonification and $\mathrm{N}_{2}$ fixation helps maintain nitrogen nutrition in resource-limited rice paddies. Biol Fertil Soils. 57:107-115. https://doi.org/10.1007/s00374-020-01508-2.

Panhwar QA, Ali A, Naher UA, Memon MY. 2019. Fertilizer management strategies for enhancing nutrient use efficiency and sustainable wheat production. Chapter 2, Organic Farming; Cambridge (GB): Woodhead Publishing Series in Food Science, Technology and Nutrition. pp. 17-39. https://doi.org/10.1016/B978-0-12-813272-2.00002-1.

Panhwar QA, Juzop S, Naher UA, Othman R, Razi MI. 2013. Application of potential phosphate-solubilizing bacteria and organic acids on phosphate solubilization from phosphate. Sci World J. 2013:272409. https://doi.org/10.1155/2013/272409.

Purwani J, Pratiwi E, Hastuti RD, Salma S, Wardana IP. 2018. Efektivitas pemupukan N, P dan $\mathrm{K}$ menggunakan pupuk hayati Agrimeth pada padi varietas Inpari 10 di lahan sawah Inceptisol Bogor. In: Zarwazi LM, Agustiani N, Margaret S, Susanti Z, Rahmini, Suprihanto, Nuryanto B, Usyati N, Herawati NA, Satoto, et al, editor. Dukungan inovasi teknologi padi untuk mewujudkan Indonesia sebagai lumbung pangan dunia. Prosiding Seminar Nasional Padi 2017; 11 Desember 2017; Subang (ID): Balai Besar Penelitian Tanaman Padi. pp. 361-372.

Puspitawati MD, Sugiyanta, Anas I. 2013. Pemanfaatan mikrob pelarut fosfat untuk mengurangi dosis pupuk $\mathrm{P}$ anorganik pada padi sawah. J Agron Indones. 41(3):188-195. 
Satapute PP, Olehkar HS, Shetti AA, Kulkarni AG, Hitemath GB, Patagundi BI, Shisvsharan CT, Kaliwal BB. 2012. Isolation and characterization of nitrogen fixing Bacillus subtilis strain AS-4 from agricultural soil. Int. J Recent Sci Res. 3(9):762-765.

Soepandi D. 2014. Fisiologi adaptasi tanaman terhadap cekaman abiotik pada agroekosistem tropika. Bogor (ID): IPB Press.

Vandana UK, Chopra A, Battacharjee S, Mazumder PB. 2017. Microbial Biofertilizer: A Potential Tool for Sustainable Agriculture. In: Panpatte D, Jhala Y, Vyas R, Shelat H (Eds). Microorganism for Green Revolution. Singapore (SG): Springer Nature Singapore Pte Ltd. pp. 25-52. https://doi.org/10.1007/978-981-10-6241-4_2.
Vyas RV, Panpatte DG, Jhala YK, Shelat HN. 2017. Wonders of microbes in agriculture for productivity and sustainability. In: Panpatte D, Jhala Y, Vyas R, Shelat H (Eds). Microorganism for Green Revolution. Singapore (SG): Springer Nature Singapore Pte Ltd. pp. 1-23. https://doi.org/10.1007/978-981-10-62414_1.

Zaidi A, Khan MS, Ahemad M, Oves M, Wani PA. 2009. Recent advances in plant growth promotion by phosphate-solubilizing microbes. In: Khan MS, Zaidi A, Musarrat J, editors. Microbial strategies for crop improvement. Berlin (DE): Springer. https://doi.org/10.1007/978-3-642-01979-1_2. 